Law $\mathcal{E}$ Social Inquiry

Volume 31, Issue 3, 711-737, Summer 2006

\title{
How Much Do Conservative Tort Tales Matter?
}

Robert A. Kagan

William Haltom and Michael McCann. 2004. Distorting the Law: Politics, Media, and the Litigation Crisis. Chicago: University of Chicago Press.

Distorting the Law: Politics, Media, and the Litigation Crisis (2004) is a pathbreaking study of the shaping of legal culture in contemporary, mediasaturated societies. It focuses particularly on the construction of a predominantly negative public image of the American tort law system. With impressive research and wit, William Haltom and Michael McCann show how and why the media has spread distorted antitort tales while neglecting sociolegal scholars' more realistic portrait of the system. One consequence, Distorting the Law indicates, is that conservative tort reformers have dominated the social construction of the tort law system in the mass media, mass culture, and political debate.

My purpose in this article is not to question Distorting the Law's excellent account of how that negative image of the tort system was shaped but to raise a perennial question about the relationship between popular discourse and political and legal change. What has been the impact of that politically inspired, media-amplified disparagement of the tort system? How much has it actually changed public opinion, the behavior of litigants, lawyers and juries, the substance of tort law, and the litigation process? These questions are not the central empirical focus of Distorting the Law. The questions focus more directly on concrete political and legal consequences than does the book as a whole. Yet Haltom and McCann do offer a "speculative argument regarding how the prevailing constructions of civil litigation in the mass media culture matter." (Haltom and McCann 2004, 29). Those constructions matter a great deal, they say in the book's final chapter, and imply the same

Robert A. Kagan is Professor of Political Science and Emanuel S. Heller Professor of Law, University of California, Berkeley. The author offers many thanks to Steve Sugarman, Jeb Barnes, Tom Burke, Joe Sanders, and Valerie Hans for insightful and informed comments and suggestions, many of which he may have inadequately implemented. 
throughout the volume. That conclusion leaves me with two puzzles I would like to address in this essay.

First, to what extent have the conservatives' tort tales actually reshaped public and politicians' attitudes toward the tort system, as opposed to merely confirming attitudes that had already been widely held? In the 1960 s and 1970 s, I will suggest, law professors, judges, and plaintiffs' lawyers brought about sharp changes in the American tort system in ways that many people have found morally troubling - not necessarily because of information gleaned from distorted tort tales in the media but because of ways in which the American tort system actually functions.

Second, if the conservative tort critics have done such a successful job in instilling a critical attitude toward the tort system in the media, the public mind, and the rhetoric of many politicians, why have the legal changes they have wrung from the courts and legislatures been relatively limited? Republican-inspired tort reform laws in the states and in Congress have only nibbled at the edges of the unique features of American tort law. They have left basically intact the four basic engines of tort litigation that make the American system (especially when viewed in comparative perspective) uniquely costly, unpredictable, and fearsome-the contingency-fee system, vague laws concerning noneconomic damages, trial by jury, and claims-aggregation through class actions. One reason, I will argue, is that notwithstanding the antitort media blitz, substantial elements of American legal culturereflecting what Lawrence Friedman (1985) characterized in terms of expectations of "total justice"-continue to support the core elements of the American tort regime, serving as a brake on conservative tort reformers' demands. In addition, I will point out, popular legal culture is only one element in the politics of legal change; organized interests, including those who benefit from and believe in the current tort system, matter as well.

To discuss these issues, I will first summarize Distorting the Law's basic findings and conclusions. Then I will review changes in American tort law that helped stimulate the conservative counterattack detailed by Haltom and McCann. Third, I will speculate about how those changes related to public attitudes. Fourth, I will examine the nature of the tort law reforms adopted by legislatures and courts in the last two decades and suggest why the those reforms been relatively minimal. Finally, I will question Distorting the Law's contention that the politically driven public discourse about tort law has "displaced" attention to broader concerns about corporate heedlessness and inequities in American society.

\section{A BRIEF (AND HOPEFULLY UNDISTORTED) TOUR OF DISTORTING THE LAW}

Haltom and McCann describe Distorting the Law as a case study in "the dynamics of the creation of legal knowledge in mass society" (Haltom and 
McCann 2004, 10). Their goal is to show "how certain legal narratives develop, circulate, and come to be accepted as a truth of social life, while many other plausible legal constructions are discarded, displaced, or diminished" (11). The case they investigate is the conservative political campaign, beginning in the 1970s, "to challenge, roll back, and otherwise reconstruct" the intensified American tort law regime that activist courts and plaintiffs' lawyers had constructed in the previous fifteen years (38). An essential strategy of that campaign, Haltom and McCann show, was to use the mass media "to condition public attitudes and to supply the public information that would advance tort reforms" (39).

Underlying that particular case study is a theoretical claim about the making and remaking of law in contemporary society. "Alluring stories that circulate in the media about law," Haltom and McCann assert, "often pervade and profoundly reshape—or ... distort-legal policymaking and ordinary legal practice itself" (11). From that perspective, popular legal culture-including the images of law generated by comedians' jokes, political soundbites, and journalistic routines-matters a great deal in influencing the path of the law. Although the last decade has seen an efflorescence of sociolegal studies of everyday legal consciousness (see, e.g., Ewick and Silbey 1998; Nielsen 2004), Distorting the Law is probably the most extended and detailed study of how deliberate political activity and the embedded routines of the mass media can influence the construction of popular legal culture.

In Part I of Distorting the Law, Haltom and McCann describe the political struggle over the American tort law system. Chapter 2, "Pop Torts," provides an eye-opening account of how the Manhattan Institute for Policy Research, financed by business interests, funded the production of polemical analyses of the American tort system by Peter Huber and Walter K. Olson, as well as reform proposals by long-time academic tort scholars such as Jeffrey O'Connell and Lester Brickman. The Manhattan Institute aggressively publicized these writings through widely circulated newsletters, conferences that attracted interested politicians, and the placement of op ed articles in major newspapers. While this established "a cerebral base for tort reforms" (Haltom and McCann 2004, 43), the American Tort Reform Association (ATRA), funded by business-oriented foundations and trade associations, spread critical views of the tort system via extensive lobbying and newspaper advertising, prodding editorial writers and Republican politicians to take public stands about the need to fix a broken and dangerous legal system.

Key to the battle for public opinion, Distorting the Law demonstrates, was the dissemination of misleading statistical data and of "tropes and slogans" designed to trigger commonsense objections to the tort system, such as references to the "litigation lottery" and the "litigation explosion" (54-55). Most important of all, Haltom and McCann argue, was the dissemination of short accounts of ostensibly outrageous lawsuits, such as one brought by the driver of a truck without brake lights who was struck from behind and injured-and 
then (supposedly) was awarded $\$ 480,000$ in "psychic damages," because his pride was hurt when his wife had to enter the labor force (62). Distorting the Law shows that not a few of such "tort tales" turn out to be apochryphal; others leave out crucial details (such as reversals on appeal, or further factual information that might make the legal outcome sound more reasonable). But the tort tales, Haltom and McCann point out, are simple, dramatic, and morally disturbing. They are easily repeated and further crystallized (emphasizing their moral offensiveness) by editorial writers, politicians, and talk show hosts. And while they are presented as emblematic of an unhinged tort law system, they convey profoundly misleading images about how the system actually functions in the processing of the great mass of tort claims.

Arrayed against the juggernaut of misleading, disparaging tort tales, Distorting the Law goes on to show, are scholars and plaintiffs' lawyers. Legal and sociolegal scholars have published in academic journals a good number of quantitative studies that debunk popular slogans concerning runaway litigation rates, the crushing economic effects of tort law, and the prevalence of irrational juries and out-of-control money damages. The American Trial Lawyers Association (ATLA) and its state-level affiliates have devoted huge campaign contributions and considerable lobbying skill to fight tort reform bills in state legislatures and Congress. ATLA often has been effective in blocking or watering down conservative tort reform bills, and in persuading state courts to hold some legislative restrictions unconstitutional. Yet ATLA's "inside politics" strategy and the scholars' carefully qualified academic articles have generated little attention in the mass media, Haltom and McCann observe. The result is that the well-planned efforts of conservative activists have dominated the public discourse about the tort system. The implication is that conversations at social gatherings and office coffee breaks, on television talk shows and at political campaign stops, have been pervaded by misleading slogans and statistics, and by tales of burglars who sue store owners after they have been injured during a break-in - not by stories of dedicated lawyers, deserving claimants, heedless defendants, and modest recoveries.

Distorting the Law demonstrates that the routines of the mass media have played a vital role in this process. Expanding on media studies by other sociolegal scholars (Bailis and MacCoun 1996; Garber and Bower 1999), Haltom and McCann identified and analyzed 3,300 litigation-related articles, editorials, and commentaries in five major newspapers ${ }^{1}$ over the 1980-1999 period. Their content analysis concluded that readers of those newspapers (and probably millions of viewers of TV news shows, which often take up stories reported in the major newspapers) would have been given the impression that litigation rates were rising much more rapidly than is the case, and also that plaintiffs win more often and win (and receive) much larger jury awards

1. The New York Times, Wall Street Joumal, Washington Post, Los Angeles Times, Christian Science Monitor. 
than actually is the case. Analyzing quotations of conservative reform proponents and tort system defenders in thematic articles (as opposed to news accounts based on particular tort cases) Haltom and McCann found that the newspapers more often reported the familiar antitort themes and slogans of the critics (Haltom and McCann 2004, 169). And Haltom and McCann conclude that, due to U.S. journalism's tendency to highlight the dramatic and to rely on out-of-court interviews with lawyers, "news narratives [like the distorted 'tort tales'] will almost always report less what transpires legally, formally, or officially in trials and more that is sensationalized, personalized, and unreliable" (174). This theme is illustrated by Haltom and McCann's imaginatively researched account of the news media's decontextualized and incomplete reporting of the famous McDonald's scalding coffee-spill case (in a chapter entitled "Java Jive"). The result, they show, is that in popular culture and political discourse, Stella Liebeck was almost invariably characterized not as an elderly victim of a corporation that knowingly disregarded the risks of severe burns posed by its product but as an offender (along with the jury and the whole tort system) against the morality of individual responsibility.

Distorting the Law also suggests that the diffusion of distorted "tort tales" is part and parcel of a broader "culture war." Haltom and McCann analogize conservative attacks on "frivolous lawsuits" to exaggerated accounts of the prevalence of "welfare queens," fortifying "general assaults on the practices of ordinary citizens in claiming rights to secure lives and remedies for harms" (30). In their final chapter, Haltom and McCann argue that the widely disseminated denunciation of national "hyperlexis" not only insulates heedless business corporations from liability but also displaces public and political attention from the failure of the tort system, and government as a whole, to provide adequate medical care for accident victims and adequate governmental regulation of various sources of harm and social injustice.

\section{THE EXPANSION AND INTENSIFICATION OF TORT LIABILITY IN THE UNITED STATES}

The antitort campaign described in Distorting the Law heated up in the 1980s. But in the preceding twenty years, the tort law system changed so rapidly that one might wonder whether it had leapt beyond public attitudes about what was appropriate and desirable. Beginning in the 1950 s but especially in the 1960s and 1970s, reform-minded state court judges and some state legislatures: (1) sharply modified the common law rule that tort claimants are barred from recovery by their own contributory negligence; (2) limited "assumption of the risk" defenses; (3) reduced governmental and charitable institutions' legal immunity from tort liability; (4) changed evidentiary rules to facilitate medical malpractice claims; (5) imposed "strict liability" for product defects; (6) expanded property-owners' liability to those injured in their 
facilities; (7) expanded the right to recover compensation for accident-related emotional distress and loss of consortium; (8) made it easier to sue out-ofstate businesses in the injured party's county courthouse; (9) empowered entrepreneurial lawyers to aggregate the claims of large numbers of accident or defective-product victims into massive class action suits; and (10) adopted the lawyer-driven pretrial discovery rules embodied in the Federal Rules of Civil Procedure, which strengthened plaintiffs' lawyers' ability to gather evidence concerning the defendant's liability (Ursin 1981, 243-44; Sugarman 1999, 456-70; Coffee 1995, 1356-58; Priest 1985, 461). All these changes made it significantly easier for plaintiffs to win tort suits and obtain larger damage awards.

These changes in law were accompanied by striking changes in the practice of tort law. After the Supreme Court held that legal restrictions on advertising by lawyers were unconstitutional, ${ }^{2}$ ads for tort lawyers blossomed on bus-stop benches and late-night television. Plaintiffs' lawyers developed sophisticated methods of "ambulance chasing," such as holding press conferences near the sites of large accidents and chemical spills, and deploying representatives to advertise for and sign up potential claimants for product liability suits. The ATLA, the Public Citizen Health Research Group, and the Center for Automotive Safety created databases and "litigation kits" for plaintiffs' lawyers, helping them to bring lawsuits concerning harms caused or allegedly caused by particular automobile models, medical products, lead paint, and silicone breast implants (Rabin 1993, 128; Stipp 1993; Kolata 1995).

Trial advocacy also changed, generating larger damage awards--which in turn attracted more and better lawyers into the plaintiffs' bar. Between 1960 and 1980, average jury awards in successful product liability and medical malpractice cases in Chicago increased more than tenfold--more rapidly than the consumer price index and the price of medical care. Verdicts in which damages exceeded $\$ 1$ million grew from 0.1 percent of all San Francisco and Chicago trials in 1960-64 to 3.5 percent in 1980-84; although such megaverdicts remained atypical, they accounted for 85 percent of the money awarded in all 1980-84 trials (Peterson 1987, 22, 33, 35, 51).

The changes in tort doctrine and practice did not induce a universal litigation explosion; as McCann and Haltom point out, the rate of tort litigation grew only modestly for many categories of accidents. Nevertheless, tort litigation became a much larger presence in significant spheres of American life. Tort claims against police departments and other officials of local governments grew dramatically (Skolnick and Fyfe 1993, 202, 300-05; Schuck 1983, 41-51, 200-01; Sherman 1992; Report of the Tort Policy Working Group 1986). Medical malpractice tort claims increased from one per one hundred American physicians in 1960 to seventeen per one hundred

2. Bates v. State Bar, 433 U.S. 350 (1977). 
in $1986 .^{3}$ Dow Chemical reported that in 1986 it incurred $\$ 100$ million in legal and insurance expenses for product liability in the United States, compared to $\$ 20$ million for such expenses on a comparable volume of manufacturing and sales elsewhere, and that it was engaged in defending 456 lawsuits in the United States, compared to only four elsewhere (Chinloy 1989, 57; Nutter and Bateman 1989). ${ }^{4}$

Tort law also became a vehicle for systematic class action litigation that could pose enormous financial threats to manufacturers of dangerous or potentially dangerous products. By expanding the grounds for circumventing state workers' compensation systems, ${ }^{5}$ federal judges opened the door to a flood of class action tort suits on behalf of victims of asbestos-caused diseasealmost 200,000 claims by 1991 , over 600,000 by 2000 and still rising (Carroll et al. 2002). By 2005, more than seventy companies, from a variety of industries that made or used asbestos, had sought bankruptcy protection. Confronted with thousands of claims on behalf of women who claimed to have suffered auto-immune damage from silicone breast-implants, Dow Corning offered a $\$ 4.23$ billion settlement, notwithstanding scientific studies that found no causal link between the implants and the plaintiffs' claimed immune system diseases (Coffee 1995, 1405-10; Angell 1996); after that settlement was rejected, Dow Corning filed for bankruptcy, later to settle remaining claims for $\$ 3.2$ billion (Bernstein 1999). Tobacco class actions, discussed in Distorting the Law, called for damages so large (hundreds of billions of dollars) that they threatened the financial viability of gigantic, previously invincible tobacco companies. These spectacular litigation campaigns were unknown before the rapid changes in the U.S. tort system in the 1960s and 1970s, and, viewed in comparative perspective, they remain unique to the American tort system.

\section{EXPLAINING THE INTENSIFICATION OF TORT LAW}

\section{A. Lawrence Friedman and "Total Justice"}

In Total Justice (1985), Lawrence M. Friedman attributed the intensification of American tort law to a long-term trend in American legal culture-rising

3. By way of comparison, there were only 1.8 malpractice claims for every one hundred Canadian physicians in 1986, and the average American physician's medical malpractice insurance bill was eleven times that of her Canadian counterpart (Dewees, Trebilock, and Coyle 1991, 219, 221; Danzon 1990, 56).

4. Similar reports come from multinational motor vehicle manufacturers (Schwartz 1991, 51; Kagan 2000). European and Japanese product liability product law changed in 1980s and 1990s, coming "reasonably close to American doctrine" (Schwartz 1991, 28; Gifford 1991, $10)$, but "the rates of litigation and the costs of liability in those countries are only a small fraction of what they are here." (Schwartz 1991, 47-51).

5. Borel v. Fiberboard Paper Products, 493 F.2d 1076 (5th Cir. 1973); Karjala v. JohnsManville Products, 523 F.2d 155 (8th Cir. 1975). 
popular expectations of "total justice," including a "general expectation of recompense" for a growing range of devastating losses. One key to this shift, he argued, was awareness of the ready availability of liability insurance, which enabled businesses, hospitals, professionals, and governments to fully compensate victims of personal injury without being driven into bankruptcy. Another key, said Friedman, was technological and scientific change. Because businesses, hospitals, and governments now had access to technologies, research methods, and organizational capabilities that enabled them to more readily identify and minimize sources of harm, it made sense for the law to require them to do so.

Such ideas, Friedman suggested, penetrated the thinking of the lawshaping governmental elite (law professors, appellate court lawyers, judges, legislative staffers, lobbyists, and journalists), causing: (1) the expansion of liability in tort law; $(2)$ the elite endorsement and enactment of more stringent environmental, safety, and consumer protection regulation and antidiscrimination laws in the 1960s and early 1970s, and the enactment of Medicaid and Medicare and disability programs; (3) the guarantee of govemmental insurance for the victims of failed savings and loan institutions, and failed private pension plans; and (4) the proliferation of governmental disaster relief and political pressures for corporate or governmental investigation of, and regulation of, the human causes of disasters of all kinds.

From the standpoint of Total Justice, therefore, the intensification of American tort law discussed above was broadly representative of America's changing legal and political culture. If so, then the conservative tort propaganda campaign described in Distorting the Law represented an effort to reshape a pro-tort-law legal culture. And if that is correct, it makes sense to question whether a legal culture attuned to "total justice," rooted in fundamental changes in modern society, could be as quickly transformed as Distorting the Law implies it has been.

\section{B. Aaron Wildavsky and Competing Political Cultures}

But was Friedman correct in seeing such widespread acceptance of the idea of total justice and the general expectation of compensation? Reviewing Friedman's book, Joseph Sanders (1987, 601-02) described how some social friends expressed dismay when they heard that a widow of a Challenger astronaut had brought a $\$ 15$ million suit against NASA under the Federal Tort Claims Act, alleging negligence in the launching of the rocket. Sanders also described how many members of an audience of Midwestern sociology graduate students and faculty were deeply disturbed to learn that courts had extended tort liability to social hosts who serve obviously intoxicated guests, knowing the guest may later operate an automobile. These responses led Sanders to argue that Friedman's account of the rise of attitudes of "total 
justice" in American legal culture-a claim that Friedman cited no opinion poll data to bolster-was, at a minimum, overstated. Clearly, other widespread attitudes were held - a viewpoint reflected in political scientist Aaron Wildavsky's (1990) analysis of the competing "political cultures" of American society.

To Wildavsky, the intensification of American tort law in the 1960s and 1970s seemed to pose a political puzzle (Polisar and Wildavsky 1989). There had been no organized, popular political movement to change tort law. To the contrary, legal scholars' accounts of those developments concentrate on the theories and influence of particular legal scholars (such as Robert Keeton, Fleming James, William Prosser, and Guido Calabresi) and of certain creative judges (such as Roger Traynor of the California Supreme Court). These legal thinkers theorized that holding manufacturers strictly liable for product injuries would be more effective than the traditional negligence standard in reducing the sum of accident costs and accident prevention costs, while spreading the cost of prevention and compensation to all consumers (Ursin 1981; Priest 1985). ${ }^{6}$ The judges, lawyers, and law professors who led the revolution in American tort law, Wildavsky argued, were members of the same class of legal activists that produced a simultaneous revolution in civil rights law, administrative law, constitutional law (criminal defendants rights, electoral redistricting, abortion rights), and regulatory law (environmental regulation, consumer protection regulation). In each of these spheres, Wildavsky maintained, the animating reform ideas reflected the same egalitarian political culture that he saw at the heart of the tort law revolutionthe notion that established authority and "corporate capitalism" cause (and hence are responsible for preventing) unjustified social inequalities and the harms that flow from abuses of economic power (Polisar and Wildavsky 1989).

Still, Wildavsky emphasized, the United States contained conflicting political cultures. "Egalitarians" reshaped tort law, constitutional law, and governmental regulation. But at the level of private morality and popular culture, he suggested, a more traditional, individualistic vision of responsibility retained a substantial hold - as Haltom and McCann acknowledge (2004, 266). Thus the elite-driven intensification of tort law probably troubled a great many Americans, whose sense of the proper limits of tort liability had been shaped by the tort law of previous generations, a law that reflected a more individualistic political culture. If that is so, the tort critics described in Distorting the Law have been preaching to a silent but philosophically

6. As George Priest (2005) describes the intellectual shift, prior to the 1960 s, tort law tended to impose liability only "where an individual was injured by an egregious breach of standards of normal behavior." The subsequent expansion of tort liability, in contrast, reflected "the acceptance by the judiciary of the proposition that civil damage judgments can serve as the most effective public policy instrument for regulating the level of harm suffered by citizens in the society." 
receptive congregation. And hence the antitort tales, by and large, arguably are reinforcing an existing set of attitudes, not reshaping American's attitudes. ${ }^{7}$

\section{The Tort System and Individualistic Values}

To support that argument, I cannot point to survey data about Americans' views about tort law over time. One cannot be sure that Sanders's friends would have been troubled by the Challenger astronaut's widow's lawsuit had it been filed in 1966, rather than in 1986, when the conservative tort reform campaign was already in high gear. But it will be useful, I think, to highlight how the American tort system conflicts with individualistic values, wholly aside from the distorted picture presented by the anti-tort campaign.

Liability Rules. One likely point of divergence with many Americans' values, underscored by Sanders' discussion of liability for social hosts, stems from the extension of tort liability beyond those who, in traditional terms, are primarily responsible for an accident-or in tort terms, are the proximate cause - to individuals and organizations who, at some prior time, had failed to take steps that could have reduced the risk of the accident. That is why, I think, the McDonald's coffee case, even if accurately told, is so striking. ${ }^{8}$ That is also why many Americans wrinkle their brows, I suspect, when they read that a shopper who had been mugged in a shopping center parking lot was allowed to recover damages from the shopping center management (Lee 1997), ${ }^{9}$ or that others similarly victimized in parking lots have recovered from landlords, ${ }^{10}$ hospitals, ${ }^{11}$ and colleges ${ }^{12}$ for failure to provide better security from muggers (Woo 1993). As a matter of public policy, there may be good reasons to shift liability to larger organizations, thereby pushing them to insure against the misuse of their products or facilities and to invest in precautionary measures. But that shift "from individual blame to system blame," as Wildavsky put it, departs sharply from an individualistic morality

7. Haltom and McCann (2004) mention this possibility, and sometimes refer to the conservative campaign as "reinforcing" traditional individualistic values (e.g., 285). But the overwhelming thrust of their rhetoric characterizes tort tales as reconstructing, reshaping, or distorting popular knowledge and attitudes.

8. In Great Britain, where there has been a much greater political commitment to collective welfare support than in the United States, when thirty-six patrons sued McDonald's for burns from extra-hot cups of coffee, a British judge dismissed the suit, saying, "I am quite satisfied that McDonald's was entitled to assume that the consumer would know that the drink was hot and there are numerous commonplace ways of speeding up cooling, such as stirring and blowing" (Ramirez 2002).

9. Abmer 4. Oakland Mall, 531 N.W.2d 726 (Mich. Ct. App. 1995).

10. Kline v. 1500 Massachusetts Avenue Apartment Corp., 439 F.2d, 477 (D.C. Cir. 1970).

11. Isaacs v. Huntington Memorial Hospital, 695 P.2d 653 (Cal. 1985).

12. Peterson v. San Francisco Community College District, 685 P.2d 1193 (Cal. 1984). 
that I suspect was broadly held well before the conservative tort-reform campaign. Similarly, many Americans, I imagine, have been troubled by plaintiffs' attorneys' increasing use of the principle of joint and several liability to seek 100 percent of their clients' damages from wealthy corporate defendants or municipalities, even when those defendants have been only a secondary or tertiary cause of the injury.

Implementation of Tort Law. Besides the extension of tort liability beyond traditional notions of responsibility, many aspects of the way tort law is implemented--in the typical case, not just the unusual tort talesseem to violate traditional individualistic values. In his justly famous "The Oven Bird's Song," David Engel (1984) observed that in Sander County, Illinois, in the 1980 s, many residents criticized tort suits but had no problem with lawsuits for debt collection. The apparent inconsistency, it seems to me, reflects the legal fact that in contract claims, the creditor-plaintiff can recover no more than what he is actually owed (plus accumulated interest for the period of nonpayment), and the standard of liability is quite in keeping with a fundamental norm of individual responsibility-keep your promises. In tort, however, a successful plaintiff can recover not only his out-of-pocket losses, as in contract, but also "noneconomic damages," such as "pain and suffering." And the standard for assessing noneconomic damages is completely vague (Blumstein, Bovberg, and Sloan 1990, 174-76; Geistfeld 1995). ${ }^{13}$ In consequence, pain and suffering settlements tend to be at least double the claimed medical bills; overall, pain and suffering damages amount to 30 or 40 percent of all compensation awarded (Blumstein et al. 1990; Geistfeld 1995).

Moreover, the claimed out-of-pocket losses often are not really economic losses at all, since, in most states, any reimbursement the plaintiff received from her own insurance is not to be taken into account in determining tort damages. ${ }^{14}$ And given the vagueness of the law, and the jury's ignorance of how similar cases are decided, and the fact that juries do not have to explain their award, and that most awards are not reviewable (or not reviewed), awards for noneconomic damages, numerous studies show, are highly variable, as are settlements (Rosenthal 1974; Hermann 1962; Kagan 2001, $113-17,138-40)$. From the standpoint of individualistic values, therefore, the tort system can be seen as deeply troubling: it produces unpredictable awards and settlements that go well beyond out-of-pocket losses, and the

13. In a typical charge, the judge tells the jury that it may award plaintiff compensation for past and future physical pain stemming from the defendant's wrongdoing, but "There are no objective guidelines by which you can measure the money equivalent of this element of injury; the only real measuring stick, if it can so be described, is your collective enlightened conscience." (Douthwaite 1988, 274).

14. In recent years, a number of states have limited or amended this "collateral source rule." See $n$. 20 below. 
amounts recovered often are disproportional to the severity of the plaintiff's injuries. ${ }^{15}$

In addition, Engel's Sander County respondents probably had some strong inkling of other morally troubling aspects of the tort system. First, as shown by a good deal of sociolegal research, plaintiffs who are unlikely to win at trial often obtain monetary settlements from the defendant's insurance company ${ }^{16}$ - especially in cases where the insurer estimates that the expense of litigation and trial are likely to exceed the amount that the plaintiff will accept. Second, the tort system often rewards padding of medical claims and engenders attempted or successful fraud (Sloane 1991, 15; Brickman et al. 1994, 33). A RAND Institute for Civil Justice Institute study yielded the astonishing estimate that "about one-third of the automobile accident medical costs submitted to insurers appear to be excess" (RAND Institute 1995, 1; Carroll et al. 1995). In 2005, a U.S. judge ordered a prominent Houston plaintiffs' law firm to pay defendants $\$ 825,000$ in legal fees following revelations of fraudulent medical tests of thousands of alleged silicosis victims (Wall Street Journal 2005a).

Hearing stories about overcompensation is all the more troublesome to many people, I imagine, because through everyday interactions they are likely to learn that the tort system often fails to compensate or undercompensates legally deserving victims of personal injury (Haltom and McCann 2004, 90; Kagan 2001, 139). Many legally strong cases involving relatively minor injuries are not even filed, turned away by plaintiffs' lawyers (or filed and later dropped), because it appears that the costs of assembling proof and litigation (including pretrial discovery) will be too great. Most victims

15. Haltom and McCann $(2004,96)$ assert that "awards for pain and suffering tend to be systematically predictable according to the severity of injuries," citing Sloan and Hsieh $(1990,1025)$; Viscusi $(1989,217-219)$. But that is not quite what those studies show. They show only that pain and suffering awards tend, in the aggregate, to bear some correlation to the severity of injuries-that is, that such awards are not random. Sloan and Hsieh (1990, $1025)$ and Bovberg et al. (1989, 923-24) show that injury severity explains only about 40 percent of the variation in pain-and-suffering awards. Research also shows that plaintiffs with similarly painful and debilitating injuries are often awarded significantly different amounts of damages (Geistfeld 1995, 784; Leebron 1989, 310; Sugarman 2005).

16. McCann and Haltom (2004) quite properly cite studies showing that the tort system tends to undercompensate plaintiffs with the most severe injuries (98), but they underemphasize research indicating that the system also often overcompensates plaintiffs with smaller and legally dubious claims (Rabin 1988, 34; Franklin 1967, 780; Munch 1977, 38-39; Bell and O'Connell 1997, 63-65). Frequent payment of settlements for questionable claims is repeatedly found by medical malpractice studies in which a panel of physicians, or physicians and lawyers, examines claim files to assess whether the defendants' negligence had caused the claimed injuries (Cheney et al. 1989, 1601-02; Metzloff 1993, 1181; Metzloff 1988; Farber and White 1991, 203-04; Sloan and Van Wert 1991, 131-68; Localio et al. 1991; Thomas, et al. 2000 (78 percent of malpractice claims in Colorado and Utah did not involve medical negligence, according to expert panel)). Distorting the Law, citing survey respondents' belief that half of liability lawsuits are not justified, suggests those impressions are due to conservative tort tales. But the medical malpractice studies indicate that the survey respondents have it right, at least with regard to that type of claim. 
of medical malpractice do not sue; and, in a sample of cases in which a physician evaluator employed by the defendant's insurance company had rated the defendant's behavior "indefensible," juries decided against plaintiffs in 43 percent of malpractice trials (Targin et al. 1992; Sanders 1998, 360).

For all these reasons-the 1960 s shift away from contributory negligence defenses and toward liability for more remote, corporate sources of harm; the elasticity of tort damage awards and settlements that go well beyond out-of-pocket losses; the frequency of recovery for weak claims; and frequent padding of claims; the system's failure to compensate many deserving people-it is plausible to believe that the tort system had a low reputation with a substantial proportion of Americans independently of the conservative effort to disparage the system. It seems likely, therefore, that the circulation of exaggerated tort tales may have been less transformative than Distorting the Law implies or assumes.

\section{CONSERVATIVE TORT REFORMS-NIBBLING AT THE EDGES}

Have the conservative efforts to sway public opinion, as detailed in Distorting the Law, rolled back the major changes in the tort system that emerged in the 1960s and 1970s? The answer is "no" or "not very far." There has been a great deal of state-level legislative action and some judicial rulings that seek to put some limits on tort litigation and noneconomic damages. But the basic changes outlined above remain intact. The conservative reforms have only nibbled at the edges of the system.

Since the mid-1980s, many states have enacted statutes that nudge tort liability rules back toward the individual-fault-based roots of tort law. Thus, many states have limited joint-and-several liability doctrines, whereby a "deep pocket" defendant who is only marginally at fault can be held responsible for all damages. The primary change in that regard has been to establish the principle of proportionate responsibility, at least for defendants whose degree of fault is minor. Reflecting the reaction of the sociologists mentioned by Sanders, some state laws have limited social hosts' liability for injuries subsequently caused by guests to whom they had served alcohol — as if to say, "sue, if you must, the major, proximate cause of your injuries, the negligent driver, not the more remote cause." 17

17. Similarly, in a number of states, legislatures have reversed or modified court decisions that had extended liability beyond the primary torfeasor, such as against a psychotherapist who failed to wam a potential victim whom the therapist's patient had threatened to harm, or against a lumber company on whose property unauthorized recreation-seekers were injured (Abel 1999). Recently a number of states have enacted statutes providing that gunmakers cannot be held liable when someone has used one of their weapons to shoot a relative of the claimant. 
A number of states have enacted modified assumption-of-the-risk defenses: a 1986 California law restricted manufacturers' and retailers' liability for inherently dangerous products that "ordinary consumers know to be unsafe," (ATRA 2004), and more recently, a number of states passed laws blocking liability suits against fast-food companies for contributing to customers' obesity-related illnesses. ${ }^{18}$

Other states have taken small steps toward making damage awards more predictable. According to ATRA (2004), eighteen states have enacted statutes imposing some limits on noneconomic damages; five other states enacted such laws, but they were held unconstitutional by state courts. Of the eighteen limiting laws, ten apply only to medical liability cases. The caps imposed ranges from $\$ 250,000$ to $\$ 1$ million; the median cap is $\$ 500,000$. Twenty-one states imposed monetary caps on punitive damages, the most common being three times compensatory damages, and many states have limited punitive damages to cases in which the jury finds the injurious behavior to be "willful or wanton" (rather than merely negligent or grossly negligent) (ATRA 2004). ${ }^{19}$

Ten state reform laws have stipulated that a substantial portion of punitive damages be paid into a state fund, rather than to the plaintiff-a change that reflects the "individualist's" concern that punitive damages represent a windfall to the plaintiff who has been awarded compensatory damages. That same ethos is reflected in the many state statutes that modify the collateral source rule, which, by providing that juries may not be told of compensation the injured plaintiff already has received from private insurance policies, enables many plaintiffs to obtain compensation for losses not really sustained. ${ }^{20}$

At the federal level, throughout the 1980s and 1990s, Congress failed to pass conservative product liability reform bills through the $1980 \mathrm{~s}$ and 1990s. In 1994, following the rapid decline of small aircraft manufacturing in the United States, Congress passed a statute restricting lawsuits against manufacturers of older piston-powered small planes (Weintraub 1994; Bryant 1995). In 2005, Congress enacted a law that seeks to restrict lawyers who assemble huge class actions from "forum shopping," that is, filing the case in those particular county courts they think will be most pro-plaintiff; the law channels

18. In addition, many states have enacted laws enacting penalties for filing frivolous lawsuits, and many have required pretrial screening panels to eliminate unmeritorious medical malpractice suits (Lavenant el al. 2002).

19. Many of these statutes also provide for a bifurcated trial, so that the jury hears evidence of the defendant's financial resources only after first deciding on liability.

20. According the ATRA (2004) summaries, seven states passed laws stipulating that collateral source payments must be subtracted from plaintiff's award, with narrow exceptions. Another seven states provided for such offsets, but with much broader exceptions. And seven other states enacted statutes simply saying that evidence of offsets can be admitted into evidence, thus giving the jury discretion to take that into account, or that grant the trial judge discretion to impose offsets. 
class actions seeking $\$ 5$ million or more into U.S. district courts. Analysts speculate, however, that there are numerous ways for plaintiffs' lawyers to continue to use the most favorable courts, at least for strong claims (Stern 2005).

The battle over tort reform also led to changes in judicial rulings. In the wake of a 1986 ballot measure, which resulted in the ouster of California Supreme Court Justice Rose Bird and two other liberals (Wold and Culver 1987), the Court issued a number of rulings restricting tort liability. As Stephen Sugarman $(1999,472)$ summed it up:

Simply put, the court now broadly opposes the imposition of liability on a defendant on the grounds that he either is well positioned to spread the cost of the accident or ... to avoid the cost of an accident. In short, Calibresian "enterprise liability" thinking is out of favor with the court. Second, the court is now strongly inclined to re-introduce more detailed rules into tort law- to take power back for judges and away from juries (and thereby to give defendants clearer idea about just what their precise legal obligations are).

Indeed, since the 1980s, judges across the United States have tended to slow the expansion of tort liability - pulling back from expansive notions of strict liability and construing causation more narrowly (Schwartz 1992; Eisenberg and Henderson 1992; Sanders and Joyce 1990). The U.S. Supreme Court ruled that huge punitive damage awards which vastly exceed actual damages can be held unconstitutional ${ }^{21}$ and urged federal trial court judges to exclude the testimony of expert witnesses who relied on uncorroborated "junk science" to draw causal connections between defendants' products and claimants' maladies. ${ }^{22}$

Overall, however, the conservative push for tort reform has produced only moderate changes in legal doctrine and the law of damages, pushing them somewhat back in the direction of individualistic values, often in ways that are arguably defensible. And as Haltom and McCann's last chapter suggests, the conservative campaign probably has produced a modest diminution in American tort litigation. ${ }^{23}$

21. BMW ข. Gore, 517 U.S. 559 (1996); State Farm Mutual Automobile Insurance Co. v. Campbell, 123 S. Ct. 1513 (2003).

22. Daubert ข. Merrill Dow Pharmaceuticals, 509 U.S. 573 (1993).

23. From 1986 to 1993, the number of tort cases filed in twenty-two selected states stopped rising, remaining steady at about 390,000 per year. Bureau of Justice Statistics, Tort Cases in Large Counties (U.S. Department of Justice, Apr. 1995). In the Columbus, Ohio, area, product liability and medical malpractice cases declined through the 1990s, defendants won most jury verdicts in such cases, and when plaintiffs won, the amounts awarded declined (Merritt and Barry 1999). Daniels and Martin's (2004) study of plaintiffs' lawyers in Texas indicates that the conservative media campaign has indeed made jurors more skeptical about lawsuits and stingier in their awards for pain and suffering-and hence has led insurance companies to be tougher and compelled plaintiffs' lawyers to eschew personal injury cases in which an accident victim's injuries are not so serious. See also Black et al. 2005; Hans 2000. 
But most important is what the conservative critics have not done or even tried to accomplish. They have not changed the rules and practices that make the American tort system uniquely accessible, costly, threatening to potential defendants, and profitable for plaintiffs' lawyers. In contrast to other democracies, the United States still has few constraints on contingency fees. It has not moved to a "loser pays" system with respect to attorneys' fees. Notwithstanding state reform laws in the late 1980s and early 1990s, the plaintiffs' bar has continued to prosecute high-profile, high-stakes class actions against manufacturers of motor vehicles with alleged design defects; manufacturers of harmful and allegedly harmful pharmaceuticals, medical devices, and food supplements; and an ever-widening array of manufacturers who used components incorporating asbestos.

Aside from some caps on "pain and suffering" and punitive damages (adversely affecting only the most severely injured plaintiffs), the reforms have not significantly constrained trial court (or jury) discretion in awarding noneconomic money damages-for example, by legislating detailed schedules for such damages in all cases, as is common in other countries. ${ }^{24}$ The conservative reforms have not significantly reduced the high cost of the lawyer-driven litigation system, or even considered displacing trial by jury, which makes the American tort system more costly and unpredictable than its counterparts abroad. And except for those victimized by the 9/11 terrorist attacks, American legislatures have not offered injured persons-and hence the business community-more comprehensive, reliable, inexpensive, collectively financed compensation mechanisms that replace, in whole or in part, an inefficient and inequitable tort litigation system.

\section{WHY CONSERVATIVE TORT REFORMS HAVE BEEN LIMITED}

If the media-amplified bark of conservative tort reformers has been worse than their bite, the question is why? More generally, in the shaping of law and legal change, how important is the legal discourse in the media and in

24. See Bovberg, Sloan, and Blumstein (1989) for an argument for more predictable painand-suffering damage schedules. Stephen Sugarman compared "pain and suffering" damages awarded in a sample of U.S. cases with the noneconomic damages that would be awarded for similar injuries in Western European countries, according to European legal experts. The sums awarded in the U.S. cases were both far less predictable and enormously greater (twenty to thirty-five times higher for very serious injuries) than the median predicted awards in Europe, and vastly higher than the highest predicted awards in Europe. Loss of a finger in the United States generated 2.5 times the median European nation pain-and-suffering award for loss of an arm. The largest amounts attainable in the most generous other nations are comparable to the caps stipulated in recent state legislation in the United States-although in "capped" states, seriously injured American plaintiffs would end up with less, on net, than European counterparts, because they would have to share a considerable share of their award with their attorneys (Sugarman 2006). 
popular consciousness, as described by Haltom and McCann, compared to other causal factors?

\section{A. The Role of Interests}

In recent decades, political scientists have explored the power of "path dependence" in shaping public policy. The basic idea is that existing institutional arrangements generate patterns of activity that continuously reinforce the attitudes and interests of those who benefit from those arrangements, producing an institutional "stickiness" that deflects and/or resists pressures for change (Pierson 2004; Hacker 2002). Laws and legal institutions, with their characteristic semiautonomy, dominance by specialists with similar legal training, and emphasis on tradition, are strong candidates for such pathdependent trajectories. ${ }^{25}$ The U.S. tort system falls in this category. As Barnes (2005) points out, tort litigation has generated increasing returns to the plaintiffs' bar, which has grown in size, sophistication, and resources. It has learned to litigate strategically to establish precedents that make future cases easier to win, to disseminate techniques for identifying and proving liability, and to influence judicial appointments and legislative policymaking (Parikh and Garth 2005). While Haltom and McCann observe that ATLA has not been very effective in shaping the public characterization of the tort system, steady and substantial funding from the plaintiff's bar has succeeded, by and large, in lining up Democratic politicians as reliable opponents of conservative tort reforms (Burke 2002, 45-51, 56; Heymann and Liebman 1988).

The ideal interests of the legal profession, too, work to resist major changes in the tort system. Legal elites--law professors, judges, lawyers in the legislatures and on legislative staffs - still tend to support the doctrinal changes of the 1960 s and 1970s. Wedded to the ideology of adversarial legalism, they defend the distinctive features of the American tort system-large contingency fees (to ensure access to lawyers and courts); class actions (to control corporate malfeasance); trial by jury (as a check on the power of judges); and wide jury discretion in assessing noneconomic damages. Plaintiffs' lawyers regularly challenge the constitutionality of conservative tort reform legislation they opposed, and at least a dozen state supreme courts have struck down key aspects of such laws, inhibiting more far-reaching conservative reform proposals.

25. Thus, Alec Stone Sweet $(2002,112)$ has written:

Given certain conditions, legal institutions will evolve in path dependent ways; that is, the social processes that link litigation and judicial law-making will build the discursive techniques and modes of decision-making specific to the exercise of judicial power; they will enhance the centrality of judicial rule-making vis-à-vis other processes; and they will, periodically but routinely, reconfigure those sites of governance constituted by rules subject to intensive litigation. 


\section{B. The Persistence of Competing Public Attitudes}

Path dependence generates obstacles to change; it does not always block it. Popular opinion sometimes becomes too insistent to resist. Hence, the battle over ideas often does matter. Yet, in the case of tort reform, Distorting the Law emphasizes only part of that story. The limited nature of the conservative tort reforms may also reflect the persistence of popular beliefs and attitudes that support core aspects of the tort system - although those attitudes may not show up strongly in Haltom and McCann's sample of news stories, which tend to focus on extreme individual cases.

Are "Total Justice" Attitudes Still Alive? As discussed earlier, from the standpoint of Friedman's Total Justice, the intensification of American tort law in the 1960s and 1970s reflected a culture that had come to expect government and courts to prevent serious accidents, illnesses, and other sources of harm and to provide compensation to the injured. Those expectations, Friedman argued, stem from fundamental social developments, such as the increasing technological and financial capacity of businesses and governments, the availability of private and public insurance, and governmental regulatory capacity. If so, those expectations would not be easy to erode, notwithstanding the circulation of the critical tort tales and the preachments of individual responsibility described in Distorting the Law.

There is plenty of evidence that expectations of "total justice" continue to exert considerable influence on American law and policymaking. Despite the shift toward conservatism in American electoral politics, political support has remained strong for broad-based social programs such as Social Security; Medicare, and Medicaid and for the core provisions of the sweeping environmental regulation programs enacted in the early 1970s. With the exception of "welfare" programs for the poor, political conservatives have had to settle for curtailing total expenditure on benefits through lowvisibility budget decisions, rather than taking the political risk of seeking substantial legislative revision of popular programs (Pierson 1994, 2000; Hacker 2002, 2004). "Welfare" for poor families was not abolished; it was restructured to limit lengthy dependency. Hurricanes and floods still compel even conservative presidents to rush compensatory aid to officially pronounced disaster areas.

Importantly; support for "total justice" is not inconsistent with much of the critique in pop tort tales. If Jones believes in "total justice," she still could (and should) rationally condemn those who unjustifiably seek compensation from government benefit-providing programs for which they are not eligible, or seek more than they deserve. She could think the same of those who file legally weak or exaggerated cases in the courts. But as a believer in "total justice," Jones still would oppose any "reforms" that would undermine the tort system's ability to punish clearly negligent businesses or government 
bodies, or its capacity to provide reasonable compensation to uninsured persons who suffered serious accidents through no fault of their own (see Hans 2000). Distorting the Law (Haltom and McCann 2004, 269) refers to surveys indicating that Americans still value the idea of being able to sue both professionals and big corporations for malfeasance.

Continued expectations of "total justice," therefore, probably have constrained political conservatives' tort reform proposals. To reiterate, conservative politicians have not sought to eviscerate the tort law system. Most of the reform laws discussed in the preceding section could be acceptable to believers in at least a moderate vision of "total justice." In 1999, California legislators thought it good politics to enact a law reinstating an injury victim's right to sue his injuror's insurance company for "bad faith" in contesting his claim (overriding a conservative 1988 California Supreme Court decision that had eliminated that previously created cause of action).$^{26}$ Similarly, the California legislature authorized medical malpractice lawsuits against health maintenance organizations for unreasonably denying or delaying coverage. ${ }^{27}$ Truly sweeping tort reform proposals have fared poorly when put directly to the electorate. In 1996, California voters were presented with three ballot initiatives designed to institute no-fault compensation for motor vehicle accidents, displacing tort law; to discourage extortive stockholder class actions; and to limit contingency fees in quickly settled cases. Opponents of the measures, led by the California Trial Lawyers' Association, bombarded the electorate with television commercials that urged voters to protect their rights to bring lawsuits. All three ballot measurers were defeated at the polls (Kagan 2001, 154).

The persistence of support for "total justice" also is suggested by the extent to which politically astute Democratic politicians like President Clinton and most Senate Democrats have fought Republican tort reform bills year after year. Democratic Senators and President Clinton sabotaged the original $\$ 360$ billion settlement of the state attorney generals' class actions against big tobacco by balking at the condition that Congress grant tobacco companies immunity from future litigation. The financial contributions and lobbying efforts of the plaintiffs' bar may provide part of the explanation, but I think the Democrats also thought large numbers of their constituents would applaud them for fighting many Republican tort law reforms, for

26. A year later, however, in 2000 , a majority of California voters passed a ballot initiative that overrode the legislatively created "bad faith" right of action. As Sugarman (2000; 2433) put it, "that election was won by the insurance industry, whose TV commercials and mass mailings overcame the campaign waged by the trial lawyers on the other side." Thus, by arguing that "total justice" still has substantial support in the American legal culture, I cannot argue that it is dominant on all issues, or that antilitigation rhetoric, tapping the legal culture of individualism, is doomed to ineffectiveness.

27. Many other states have authorized malpractice suits against HMOs, although in some cases, the claimant must first exhaust an administrative remedy. 
refusing to grant tobacco companies immunity from tort liability, and for preserving the right to trial by jury and to sue the powerful. ${ }^{28}$

What Do Conservatives Want? One more reason the conservative reforms have only nibbled at the edges of the tort system may be that "nibbling" is all many (or most) conservatives really want. As Sugarman (1998) has pointed out, conservatives tend to like the fundamental philosophy of tort law, which focuses on individual responsibility for serious misconduct. Many conservatives may prefer a decentralized, citizen-activated tort system to tougher governmental regulation and to government-run injury-compensation programs, which threaten to increase total costs and could be captured by liberal bureaucrats or politicians. Hence at bottom, conservatives may really dislike only certain "excesses" of the tort systemweakly-founded but expensive-to-defend lawsuits, padded claims, the shift of responsibility to secondarily-responsible corporate actors, huge "betyour-company" class actions based on questionable cause-effect relationships, escalating liability insurance costs due to the unpredictability of very large jury awards. Or more cynically, Republic politicians, by denouncing excessive litigation and pressing limited (and often porous) reform bills, may have found a low-cost way of appealing to the many "individualists" in the electorate, while eschewing more radical reform proposals that could result in an electoral backlash. ${ }^{29}$

\section{HAVE TORT TALES DISPLACED A LIBERAL POLITICAL AGENDA?}

In Chapter 8 of Distorting the Law, Haltom and McCann argue that the conservative tort law campaign and the dissemination of distorted tort tales have diverted journalistic and political attention from other important issues-such as injurious corporate behavior and the inequities that stem from corporate power $(282,287)$ - thereby insulating corporations and "corporate greed" from responsibility $(282,285, \mathrm{n} 22)$. In these and other passages, Haltom and McCann make tort reform discourse a key cause of what they see as core political and social failings. In doing so, they are far less intellectually rigorous than they are in the rest of Distorting the Law. Their rhetoric, for example, assumes that had there been no conservative antitort campaign, the news

28. Law professor Michael Asimow (2005, 3), surveying the history of lawyering in American television programs and motion pictures, concludes that even as popular culture conveys distrust of lawyers in general, "Popular culture has taught us to trust adversarialism and to regard the lawyer as the champion for our personal interests, indeed for our liberty. Almost from the cradle, we have been absorbing narratives that glorify the work of lawyers in securing justice. Even more important, these narratives teach us that the adversarial system discovers the truth about what really happened."

29. I am indebted to Tom Burke for this idea. 
media (and hence politicians) would have devoted much more attention to investigations and critiques of corporate activity, to detailed analyses of dangerous products and their corporate causes, to the tort law system's (and the health care system's) failures in providing compensation for personal injury, and to governmental inaction concerning various social and economic inequalities. That is conceivable, but Haltom and McCann's own analysis of the norms and incentives of contemporary journalism (i.e., to focus on dramatic, easily assembled-and-told stories) makes it seem far from likely.

A second assumption is that the antitort campaign has been an important factor in blocking governmental action on more pressing social issues. "Invocations of lawsuit frenzy," they write (293), "have neutralized calls for new, more expansive social welfare and regulatory programs." But Haltom and McCann do not tell us what specific regulatory or social welfare enactmentsparticularly any that would have had some realistic chance of being enacted by a Republican Congress or most state legislatures in the 1990s and 2000shave been shoved off the political agenda by the hyperlexis stories. ${ }^{30}$ One could point to a number of "nonenactments"-failure to extend health care benefits to part-time or low-wage workers, to enact regulatory restrictions on employers' shift away from defined-benefit pensions, to impose much stricter emissions controls on SUVs and small trucks, to provide better funding for OSHA's enforcement program, and many others. But such nonenactments probably are far less attributable to "invocations of lawsuit frenzy" in the press than to a variety of political factors, such as the declining political power of organized labor in a globalized economy, the suburbanization of the American electorate, the Republican Party's control of Congress and (since 2001) the presidency, and a more general political shift away from support for expensive "big government" initiatives.

And is it really true that issues of risk, harm, and corporate malfeasance have been displaced in the public discourse? In the last fifteen years, there have been many news media accounts, vigorous political debates, and some important regulatory initiatives on numerous "issues of risk and harm in contemporary life"-prevention of petroleum spills (in the wake of the Exxon Valdez disaster), reductions in diesel engine emissions, deterrence of fraud in reporting corporate earnings, reductions in $\mathrm{SO}_{2}$ emissions from coal-fired power plants, improved safety features in motor vehicles and mandatory use of child safety seats, new mandatory early childhood vaccines, reduction in chlorine (and hence dioxin) in industrial effluent (Gunningham et al. 2003), and many more. Haltom and McCann, and most readers, could compose an equally lengthy wish-list of risks and harms that have not been addressed. But it is hard to be convinced that the cause is "displacement" by hyperlexis

30. I am not suggesting that Haltom and McCann were obliged to set forth their own policy agenda, for that is not the nature or purpose of Distorting the Lau, but only that their claim of policy displacement might have been more persuasive, as an empirical matter, had they listed some politically plausible examples. 
talk when many issues do seem to find their way through or around the tort-discourse fog.

Similarly, Distorting the Law suggests that media coverage of the massive class action suits against tobacco companies, by focusing on issues of liability under the fault principles of tort law, has fumbled "the opportunity to ask questions about the institutional failures of Congress to regulate effectively or ban lethal products" (291). But Haltom and McCann do not say which lethal products ought to be banned, or which current regulatory laws are inadequate. I do not think tort case coverage is a significant factor in explaining why Congress has not banned handguns or cigarettes, or regulated fat content in fast food servings. Nor has there has been any paucity of media attention to the lethal quality of those and other products. Hence in this regard, as throughout the last chapter, Haltom and McCann seem to be making distorted tort discourse the scapegoat for the American polity's failure to promulgate more liberal laws and public policies.

\section{CONCLUSION}

The core of Distorting the Law is an original, well-conceived, and diligently documented account of the conservative campaign against certain features of American tort law, and about how and why distorted, poorly contextualized negative "tort tales" have come to dominate the discourse about tort law in the media and in American culture. But Haltom and McCann claim (or imply) too much about the impact of the public discourse they skillfully present.

To a difficult-to-determine but significant extent, I have suggested, the conservative tort tales resonated with many Americans who already had been troubled by aspects of tort system that stemmed from its rapid transformation in the 1960s and 1970s. Hence, the conservative campaign probably reinforced existing doubts at least as much as it lured previous tort law supporters into dissent. Moreover, Distorting the Law spends little time exploring the extent to which many politicians and significant elements of the publicas well as members of the legal profession-have continued to support the core elements of the tort law system. That support may explain why the antitort campaign, while looming large in the mass media, has not produced significant change in the basic laws, institutional arrangements, and litigation practices that make American tort law, even after the conservative reforms of recent decades, uniquely powerful, threatening, costly, inefficient, and erratic. Distorting the Law demonstrates that analyzing the generation of mass legal discourse is a fascinating enterprise. But that discourse, I am sure scholars as sophisticated as Haltom and McCann would agree, is only one variable among many-including material and political interests, the "stickiness" of entrenched institutional and legal arrangements, and the complex interplay of competing values-in determining the path of the law. 


\section{REFERENCES}

Abel, Richard. 1999. Questioning the Counter-Majoritarian Thesis: The Case of Torts, DePaul Law Review 49:533.

Angell, Marcia. 1996. Science on Trial: The Clash of Medical Evidence and the Law in the Breast Implant Cases. New York: Norton.

Asimow, Michael. 2005. "Popular Culture and the American Adversarial Ideology." Paper presented at the Annual Meeting of the Law and Society Association, Las Vegas, $\mathrm{NV}$, June $2-5$.

ATRA. 2004. ATRA Tort Reform Record. http://www.atra.org.

Bailis, Daniel, and Robert MacCoun. 1996. Estimating Liability Risks with the Media as Your Guide: A Content Analysis of Media Coverage of Tort Litigation. Law and Human Behavior 20:419-29.

Barnes, Jeb. 2005. "Is Adversarial Legalism Path Dependent? Congressional Inertia and Court-Based Tort Reform during the Asbestos Crisis." Paper Prepared for the 2005 Annual American Political Science Association Conference, Washington, DC.

Bell, Peter, and Jeffrey O'Connell. 1997. Accidental Justice: The Dilemmas of Tort Law. New Haven, CT: Yale University Press.

Bernstein, David. 1999. The Breast Implant Fiasco. California Law Review 87:457.

Black, Bernard, Charles Silver, David Hyman, and William Sage. 2005. Stability, Not Crisis: Medical Malpractice Claim Outcomes in Texas, 1988-2002. Journal of Empirical Legal Studies 2:207-59.

Blumstein, James, Randall Bovberg, and Frank Sloan. 1990. Beyond Tort Reform: Developing Better Tools for Assessing Damages for Personal Injury. Yale Journal on Regulation 8:171.

Bovberg, Randall, Frank Sloan, and James Blumstein. 1989. "Valuing Life and Limb in Tort: Scheduling Pain and Suffering," Northwestern Law Rev. 83:980.

Brickman, Lester, Michael Horowitz and Jeffrey O'Connell. 1994. Rethinking Contingency Fees. New York: The Manhattan Institute.

Bryant, Adam. 1995. Small Planes are Coming Back. New York Times, Mar. 19, F11 (L).

Burke, Thomas. 2002. Lawyers, Lawsuits, and Legal Rights: The Battle over Litigation in American Society. Berkeley: University of California Press.

Carroll, Stephen et al. 2002. Asbestos Litigation Costs and Compensation: An Interim Report. Santa Monica, CA: RAND Institute for Civil Justice.

Carroll, Stephen, Allan Abrahamse, and Mary Vaiana. 1995. The Costs of Excess Medical Claims for Automobile Personal Injuries. Santa Monica, CA: RAND Institute for Civil Justice.

Cheney, Frederick W. et al. 1989. Standard of Care and Anesthesia Liability. Joumal of the American Medical Association 261:1599.

Chinloy, Peter. 1989. The Cost of Doing Business: Legal and Regulatory Issues in the United States and Abroad. New York: Praeger.

Coffee, Jr., John C. 1995. Class Wars: The Dilemma of the Mass Tort Class Action. Columbia Law Review 95:1343.

Daniels, Stephen, and Joanne Martin. 2004. The Strange Success of Tort Reform. Emory Law Joumal 53:1225.

Danzon, Patricia. 1990. The "Crisis" in Medical Malpractice: A Comparison of Trends in the United States, Canada, the United Kingdom and Australia. Law, Medicine \&3 Health Care 18:48.

Dewees, Donald, Michael Trebilcock, and Peter Coyte. 1991. The Medical Malpractice Crisis: A Comparative Empirical Perspective. Law and Contemporary Problems $54: 217-51$. 
Douthwaite, Graham. 1988. Jury Instructions on Damages in Tont Actions. 2nd ed. Charlottesville, VA: Michie Co.

Eisenberg, Theodore, and James Henderson, Jr. 1992. Inside the Quiet Revolution in Products Liability. UCLA Law Review 39:731.

Engel, David. 1984. The Oven Bird's Song: Insiders, Outsiders, and Personal Injuries in an American Community. Law $\mathcal{E}$ Society Review 18:551.

Ewick, Patricia, and Susan S. Silbey. 1998. The Common Place of Law: Stories from Everyday Life. Chicago: University of Chicago Press.

Farber, Henry, and Michelle White. 1991. Medical Malpractice: An Empirical Examination of the Litigation Process. RAND Joumal of Economics 22:199.

Franklin, Marc. 1967. Replacing the Negligence Lottery: Compensation and Selective Reimbursement. University of Virgina Law Review 53:774.

Friedman, Lawrence M. 1985. Total Justice. New York: Russell Sage Foundation.

Garber, Steven, and Anthony Bower. 1999. Newspaper Coverage of Automotive Product Liability Verdicts. Law B Society Review 33:93-122.

Geistfeld, Mark. 1995. Placing a Price on Pain and Suffering: A Method for Helping Juries Determine Tort Damages for Nonmonetary Injuries. Califormia Law Review 83:773.

Gifford, Donald G. 1991. The American Tort Liability System. In Werner Pfennigsdorf with Donald Gifford, A Comparative Study of Liability Law and Compensation Scheme in Ten Countries and the United States. Oak Brook, IL: Insurance Research Council.

Gunningham, Neil, Robert A. Kagan, and Dorothy Thornton. 2003. Shades of Green: Business, Regulation, and Environment. Stanford, CA: Stanford University Press.

Hacker, Jacob. 2002. The Divided Welfare State: The Battle Over Public and Private Social Benefits in the United States. Cambridge, MA: Cambridge University Press.

- 2004. Privatizing Risk without Privatizing the Welfare State: The Hidden Politics of Social Policy Retrenchment in the United States. American Political Science Review 98:243-60.

Haltom, William, and Michael McCann. 2004. Distorting the Law: Politics, Media and the Litigation Crisis. Chicago: University of Chicago Press.

Hans, Valerie. 2000. Business on Trial: The Civil Jury and Corporate Responsibility. New Haven, CT: Yale University Press.

Hans, Valerie, and William Lofquist. 1992. Jurors' Judgments of Business Liability in Tort Cases: Implications for the Litigation Explosion Debate. Law $\mathcal{B}$ Society Review 92:85-115.

Hermann, Philip. 1962. Predicting Verdicts in Personal Injury Cases. Insurance Law Joumal 475:505.

Heymann, P., and L. Liebman. 1988. No Fault, No Fee: The Legal Profession and Federal No-Fault Insurance Legislation. In The Social Responsibilities of Lawyers, ed. P. Heymann and L. Liebman. Westbury, NY: Foundation Press.

Kagan, Robert A. 2001. Adversarial Legalism: The American Way of Law. Cambridge, MA: Harvard University Press.

Kolata, Gina. 1995. Will the Lawyers Kill Off Norplant? New York Times, May 28, sec. 3, 1, 5.

Lee, Louise. 1997. Lots of Trouble: Courts Begin to Award Damages to Victims of ParkingArea Crime. Wall Street Joumal, Apr. 23, A1.

Leebron, David. 1989. Final Moments: Damages for Pain and Suffering Prior to Death, NYU Law Review 64:256.

Levanant, Claudia, Craig Hayward, and Paul Jesilow. 2002. Tort Reform and Physician Sanctioning. Law $\&$ Policy 24:17-35.

Lipset, Seymour Martin. 1996. American Exceptionalism: A Double-Edged Sword. New York: W. W. Norton.

Localio, A.R. et al. 1991. Relation Between Malpractice Claims and Adverse Events Due to Negligence. New England Journal of Medicine 325:245-51. 
Mertitt, Deborah, and Kathryn Barry. 1999. Is the Tort System in Crisis? New Empirical Evidence. Ohio State Law Joumal 60:315.

Metzloff, Thomas B. 1988. Researching Litigation: The Medical Malpractice Example. Law \& Contemporary Problems 51:199.

- 1991. Resolving Malpractice Disputes: Imaging the Jury's Shadow. Law $\mathscr{E}$ Contemporary Problems 54:43.

Munch, Patricia. 1977. Costs and Benefits of the Torts System if Viewed as a Compensation System. Santa Monica, CA: RAND Corporation Institute for Civil Justice.

Nielsen, Laura Beth. 2004. License to Harass: Law, Hierarchy and Offensive Public Speech. Princeton, NJ: Princeton University Press.

Nutter, Franklin, and Keith Bateman. 1989. The U.S. Tort System in the Era of the Global Economy. Schaumberg, IL: Alliance of American Insurers.

Parikh, Sara, and Bryant Garth. 2005. Philip Corboy and the Construction of the Plaintiff's Personal Injury Bar. Law \& Social Inquiry 30:269.

Peterson, Mark. 1987. Civil Juries in the 1980s: Trends in Jury Trials and Verdicts in California and Cook County, Illinois. Santa Monica, CA: RAND Corporation Institute of Civil Justice.

Pierson, Paul. 1994. Dismantling the Welfare State? Reagan, Thatcher, and the Politics of Retrenchment. New York: Cambridge University Press.

- ed. 2000. The New Politics of the Welfare State. Oxford: Oxford University Press.

Polisar, Daniel, and Aaron Wildavsky. 1989. From Individual to System Blame: A Cultural Analysis of Historical Change in the Law of Torts. Journal of Policy History 1:129.

Priest, George L. 1985. The Invention of Enterprise Liability: A Critical History of the Intellectual Foundations of Modern Tort Law. Joumal of Legal Studies 14:461.

—. 2005. "The Modern Transformation of Civil Law." Paper presented at Common Good/AEI-Brookings conference on "Lawsuits and Liberty," Philadelphia, PA, June $27-28$.

Rabin, Robert. 1988. Some Reflections on the Process of Tort Reform. San Diego Law Review 25:24.

_. 1993. Institutional and Historical Perspectives on Tobacco Tort Liability. In Smoking Policy: Law, Politics, and Culture, ed. R. Rabin and S. Sugarman. New York: Oxford University Press.

Ramirez, Anthony. 2002. Hot Water: For McDonald's, British Justice Is a Different Cup of Tea. New York Times, Apr. 7.

RAND Institute for Civil Justice. 1995. How Big Is the Price Tag for Excess Auto Injury Claims? RAND Institute for Civil Justice Research Brief (May), 1.

Report of the Tort Policy Working Group on the Causes, Extent and Policy Implications of the Current Crisis in Insurance Availability and Affordability. 1986. Washington, DC: Government Printing Office.

Rosenthal, Douglas. 1974. Lawyer and Client: Who's in Charge? New York: Russell Sage Foundation.

Sanders, Joseph. 1987. The Meaning of the Law Explosion: On Friedman's Total Justice. American Bar Foundation Research Joumal 1987:601. 1998. Scientifically Complex Cases, Trial by Jury, and the Erosion of Adversarial Processes. Depaul Law Review 48:355.

Sanders, Joseph, and Craig Joyce. 1990. "Off to the Races": The 1980s Tort Crisis and the Law Reform Process. Houston Law Review 27:207.

Sherman, Lawrence. 1992. The Influence of Criminology on Criminal Law: Evaluating Arrests for Misdemeanor Domestic Violence. Joumal of Criminal Law $\&$ Criminology $83: 1$.

Schuck, Peter. 1983. Suing Government: Citizen Remedies for Official Wrongs. New Haven, CT: Yale University Press. 
Schwartz, Gary. 1991. Product Liability and Medical Malpractice in Comparative Context. In The Liability Maze, ed. Peter Huber and Robert Litan. Washington, DC: Brookings Institute.

- 1992. The Beginning and the Possible End of the Rise of Modern American Tort Law. Georgia Law Review 26:601.

Skolnick, Jerome, and James Fyfe. 1993. Above the Law: Police and the Excessive Use of Force. New York: The Free Press.

Sloan, Frank, and Chee Ruey Hsieh. 1990. Variability in Medical Malpractice Payments: Is the Compensation System Fair? Law EO Society Review 24:997.

Sloan, Frank A., and Stephen S. Van Wert. 1991. Cost and Compensation of Injuries in Medical Malpractice. Law \&ु Contemporary Problems 54:131.

Sloane, Leonard. 1991. Rising Fraud Worrying Car Insurers. New York Times, Nov, 16, 15.

Stern, Seth. 2005. Lawyers Seek Loopholes in Class Action Overhaul, CQ Weekly, Feb. 28, 494.

Stipp, David. 1993. Dogma in Doubt: Extent of Lead's Risk to Kids, Need to Remove Paint. Wall Street Joumal, Sept. 16, A1, 12.

Stone Sweet, Alec. 2002. Path Dependence, Precedent, and Judicial Power. In Martin Shapiro and Alex Stone Sweet, On Law, Politics, and Judicialization. London: Oxford University Press.

Sugarman, Stephen D. 1998. Personal Injury and Social Policy-Institutional and Ideological Alternatives. In Torts Tomorrow: A Tribute to John Fleming, ed. N. Mullany and A. Linden. Sydney: LBC Information Services.

- 1999. Judges as Tort Law Un-Makers: Recent California Experience with "New" Torts. DePaul Law Review 49:455.

- 2000. A Century of Change in Personal Injury Law. California Law Review 88:2403. 2006. A Comparative Look at Pain and Suffering Awards. DePaul Law Review 55:399.

Taragin, Mark et al. 1992. The Influence of Standard of Care and Severity of Injury on the Resolution of Medical Malpractice Claims. Annals of Internal Medicine 117:780.

Thomas, E. J. et al. 2000. Incidence and Types of Adverse Events and Negligent Care in Utah and Colorado. Medical Care 38 (3): 261-71.

Ursin, Edmund. 1981. Judicial Creativity and Tort Law. George Washington Law Review 49:229.

Wall Street Joumal. 2005. The Silicosis Sheriff. July 14, A10.

Weintraub, Richard. 1994. Waiting on the Fields of Flight. Washington Post, June 7, D1.

- 1994. House Panel Backs Aircraft Liability Limits. Washington Post, June 22, F2.

Wildavsky, Aaron. 1990. A World of Difference-The Public Philosophies and Political Behaviors of Rival American Cultures. In The New American Political System, ed. Anthony King, 2nd version. Washington, DC: AEI Press.

Viscusi, W. Kip. 1989. Toward a Diminished Role for Tort Liability: Social Insurance, Government Regulation, and Contemporary Risk to Health and Safety. Yale Joumal on Regulation 6:65-97.

Wold, Jon, and John Culver. 1987. The Defeat of the California Justices. Judicature Apr./May.

Woo, Junda. 1993. Legal Beat: Business Finds Suits on Security Hard to Defend. Wall Street Journal, Sept. 1, B1.

\section{CASES CITED}

Abner v. Oakland Mall, 531 N.W.2d 726 (Mich. Ct. App. 1995).

Bates v. State Bar, 433 U.S. 350 (1977). 
BMW v. Gore, 517 U.S. 559 (1996).

Borel v. Fiberboard Paper Products, 493 F.2d 1076 (5th Cir. 1973).

Daubert v. Merrill Dow Pharmaceuticals, 509 U.S. 579 (1993).

Isaacs v. Huntington Memorial Hospital, 695 P.2d 653 (Cal. 1985).

Karjala ข. Johns-Manville Products, 523 F.2d155 (8th Cir. 1975).

Kline v. 1500 Massachusetts Avenue Apartment Corp., 439 F.2d 477 (D.C. Cir. 1970).

Peterson v. San Francisco Community College District, 685 P.2d 1193 (Cal. 1984).

State Farm Mutual Automobile Insurance Co, v. Campbell, 123 S. Ct. 1513 (2003). 
$* * *$

HeinOnline -- 31 Law \& Soc. Inquiry 7382006 